\title{
超低粘度塗工用澱粉の利用*1
}

王子コーンスターチ株式会社 ${ }^{* 2}$ 開発研究所 石 田 光 雄

\section{Use of Superlow Viscosity Modified Starch for Coating}

\section{Mitsuo Ishida}

Research and Development Laboratory, Oji Cornstarch Co., Ltd.. ${ }^{* 2}$

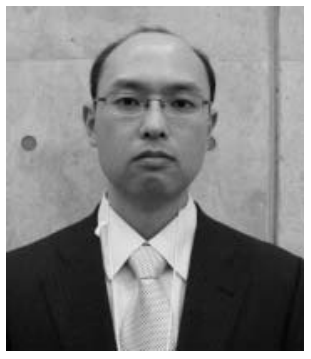

\begin{abstract}
Recently development of printing technology requires high quality printing paper but also low ${ }^{-}$cost paper, $^{-}$ so that paper mills have improved productivity and cost of color materials. They require the material that is able to make high solid and high speed coating color.

We have developed superlow viscosity modified starch, it's named “HSS COAT". Usually if it uses a low viscosity starch for coating color, surface strength of its coated paper is very week. But using of HSS COAT is able to maintain the surface strength of coated paper. Besides it can be prepared with higher solid coating color, so that coated paper quality, including such as gloss etc., is improved, and it's probable to reduce latex.
\end{abstract}

We would like to recommend using of HSS COAT for coating color.

分類 $: \mathrm{W}_{8}$ 塗料調整薬品, $\mathrm{S}_{5}$ 塗工印刷用紙（微塗工印刷用紙を含む）

\section{1.はじめに}

塗工紙は印刷技術の高度化が進み, 非常に印刷用紙に対 する要求が高度化されてきているが，近年はそれ以上にコ ストダウンが求められている。塗料材料の中では顔料構成 の見直しや, 顔料に次いで多く用いられているバインダー コストの削減が行われている。また，生産性向上のために 塗工の高速化, 塗工後の乾燥エネルギー低減等が求められ ている。

塗料に用いられるバインダーとしてはラテックスや澱粉 が挙げられる。ラテックスは澱粉に比べて顔料接着のバイ ンダー機能は大きく, 普通は澱粉よりも塗料に添加される 割合が高い。但し，保水性付与の機能は澱粉の方が大きく， コストの面からも一般的にはラテックス単独よりも澱粉を 併用することが多い。通常の塗料用澱粉はラテックスより も安価ではあるが粘性が大きい為, 塗料に多く添加すると 塗料粘度が増大し, 塗工速度の向上や塗料の高濃度化が難

\footnotetext{
${ }^{* 1}$ 平成 21 年度年次大会講演（講演 No. C 2)

*2 个290-0067 千葉県市原市八幡海岸通り 9/9 Kaigandori,

Yahata, Ichihara-shi, Chiba 290-0067, Japan
}

しくなる。単純に澱粉の粘度を低下させ，塗料の粘度を抑 制する事は可能であるが, 澱粉の粘度低下はバインダー機 能低下にも繋がり, 且つ, 保水性機能の低下も招くことに なる。

澱粉の低粘度化はフィルム強度低下を招き，バインダー としての機能が低下する傾向であるが, 反面, 粘度が低い 為に塗料用のバインダーとしては顔料スラリー中での分散 状態が良くなり, 顔料間に糊剂が混合され易くなると考え られる。また，澱粉特有の「老化現象」によるバインダー 機能低下も抑制する事が可能である。そこで弊社は塗料用 の超低粘度澱粉「HSS コート300」を開発した。HSS コ ート 300 は非常に低粘度の澱粉ではあるが, 塗料用バイン ダーとして用いると塗工紙の光沢性が向上し, 塗料の処方 によっては印刷強度の向上も見られる。また, HSS コー 卜 300 を用いた塗料は粘度物性が低くなる為, 塗料の高濃 度化，澱粉の添加量を増やせる可能性がある。

本報では低粘度澱粉の塗料用バインダーとしての可能性 を追求する為, 超低粘度澱粉「HSS コート 300」の塗料用 澱粉として最も効果的な利用方法の検討について報告する。 


\begin{tabular}{l|c|c|c}
\multicolumn{2}{c}{} & \multicolumn{2}{c}{ 石 } \\
\cline { 2 - 4 } \multicolumn{2}{c}{ 表 1} & HSS コートシリーズ \\
\hline & 粉体白度 & スラリー $\mathrm{pH}(10 \%)$ & B 型粘度 $\left(35 \mathrm{w} / \mathrm{w} \%, 50{ }^{\circ} \mathrm{C}\right)$ \\
\hline HSS コート 300 & $75 \%$ & 5.5 & $200 \mathrm{mPa} \cdot \mathrm{s}$ \\
\hline HSS コート 100 & $80 \%$ & 5.5 & $400 \mathrm{mPa} \cdot \mathrm{s}$ \\
\hline
\end{tabular}

\section{2. 超低粘度澱粉「HSS コート 300」について}

澱粉の低粘度化には一般に酸変性反応，酸化変性反応， 酵素変性反応，熱変性反応があるが，どの反応も単純に澱 粉に作用させると澱粉分子を乱雑に切断し，澱粉分子の再 凝集化, 再結晶化といった, 所謂「澱粉の老化」を引き起 こす恐れがある。この老化現象が進行すると, 澱粉糊液の 粘度が上昇したり，不溶性の凝集物が多く発生する。この 事態を防ぐ為に澱粉分子の水酸基にエステル基，エーテル 基を導入したり，低分子化反応の制御を行ったりする。但 し，エステル，エーテル基を多く導入すると老化防止にな るが, 塗料中の顔料や他の薬品と相互作用を生じ, カラー ショックを生じる場合があるので注意が必要である。

HSS コートシリーズには現在粘度の異なる 2 種類の製 品があるが (表 1), 何れも低粘度の低化工リン酸エステ ル化澱粉である。今回は最も粘度が低い「HSS コート 300」 についての検討を行った。

HSS コート 300 は澱粉粘度が低い事もあるが，他の澱 粉に比べて糊液の老化性が非常に小さく，糊液の粘度安定 性にも非常に優れている（図 1，図 2)。また，澱粉スラリ

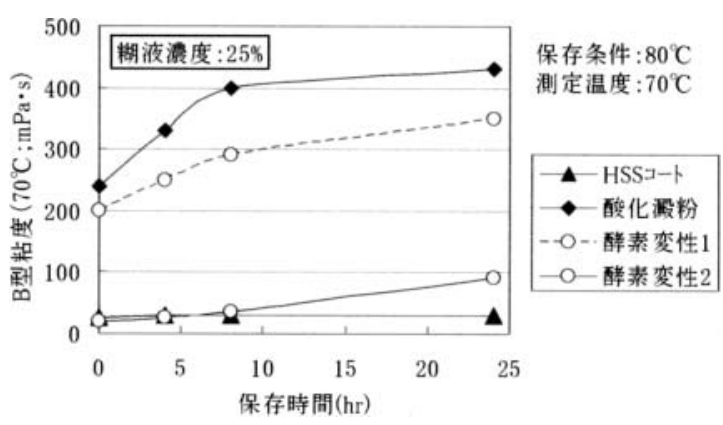

図 1 澱粉糊液の $80^{\circ} \mathrm{C}$ 保存経時粘度

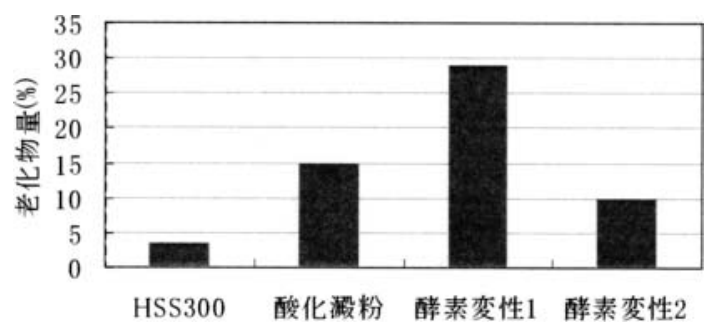

[老化物量測定条件]

• $25 \%$ クッキング後， $80^{\circ} \mathrm{C}, 24 \mathrm{hr}$ 糊液を保存。

・保存糊液サンプルを熱水で希釈し， $4,500 \mathrm{rpm}, 10 \mathrm{~min}$ 遠心処理。 上澄液を捨て, 熱水で洗浄。残渣物の乾燥重量を測定し, 糊液固 形分に対する割合を求める。

図 2 保存糊液老化物量

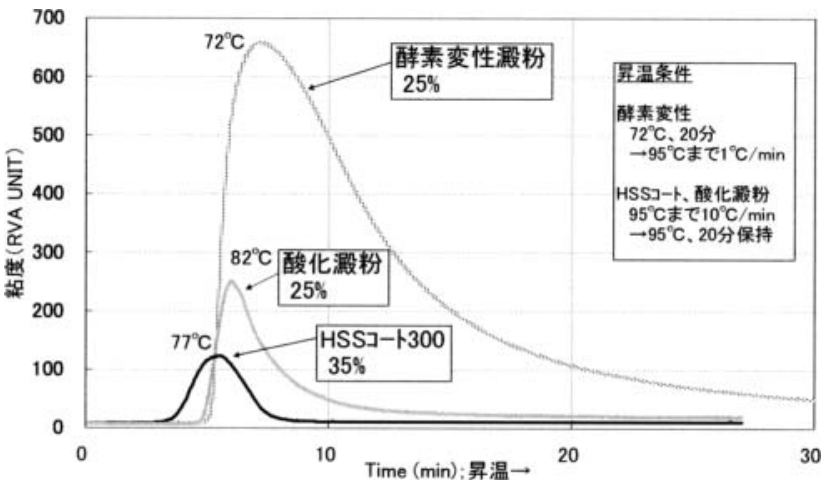

図 3 RVA (rapid viscosity analyzer) による澱粉アミロ グラフ測定

一（澱粉粉体を水中に分散させたもの）を加熱して糊に仕 上げるクッキングの際，澱粉は出来上がり粘度よりも非常 に大きな粘度（ピーク粘度）を発現させるが，HSS コー 卜は高濃度でクッキングしても他の澱粉よりもピーク粘度 が低く, クッキング装置の攪汼力負荷が小さくて済む為, 高濃度のクッキングが可能である（図 3）。

\section{3. 塗工評価}

今回は低粘度澱粉利用による塗料，塗工紙品質の特徴を 検討する為，塗料用澱粉として広く一般的に使用されてい る酸化澱粉（エース A ; 王子コーンスターチ製）を用い た処方との比較を行った。また，ラテックスはスチレンー ブタジエン系を使用した。

\section{1 塗料 配 合}

塗料配合処方を表 2 に示す。使用顔料による接着力効果 の違いを確認する為，カオリン/重質炭酸カルシウム（以

表 2 塗料配合 (部数)

\begin{tabular}{l|c|c|c|c|c|c|c}
\hline \multicolumn{1}{c|}{ 処方記号 } & $\mathrm{A}$ & $\mathrm{B}$ & $\mathrm{C}$ & $\mathrm{D}$ & $\mathrm{E}$ & $\mathrm{F}$ & $\mathrm{G}$ \\
\hline カオリン & 60 & 50 & 40 & 20 & 50 & 50 & 50 \\
\hline 重炭 & 40 & 50 & 60 & 80 & 20 & & 50 \\
\hline 軽炭 & & & & & 30 & 50 & \\
\hline 澱粉 & 3 & 3 & 3 & 3 & 3 & 3 & 4.5 \\
\hline ラテックス & 10 & 10 & 10 & 10 & 10 & 10 & 9 \\
\hline
\end{tabular}

カオリン: UW-90, 重炭: FMT-90, 軽炭： $\mathrm{TP}-123$

※澱粉のクッキングは特に断りがない限り, HSS コートは 35\%，酸化澱粉は $25 \%$ とした。 
表 3 塗工紙作成条件

\begin{tabular}{l|l}
\hline 塗工原紙 & 上質紙 $60 \mathrm{~g} / \mathrm{m}^{2}$ (サイズプレス処理品) \\
\hline 塗工速度 & $25 \sim 35 \mathrm{~m} / \mathrm{min}$ \\
\hline 乾燥条件 & 熱風乾燥 (炉内温度 $\left.130^{\circ} \mathrm{C}\right), 10 \mathrm{sec}$ \\
\hline 塗工量 & $9.5 \mathrm{~g} / \mathrm{m}^{2}$ \\
\hline カレンダー条件 & $100 \mathrm{~kg} / \mathrm{cm}, 3$ 回処理 \\
\hline
\end{tabular}

下重炭）配合の違い，重炭の代わりに軽質炭酸カルシウム (以下軽炭）を用いた場合の影響を検討した。また，澱粉 とラテックスの添加部数は $3 / 10$ 部を基本としたが, ラテ ックスを減添し，代わりに澱粉を増添させた場合の影響や， 塗工濃度による影響, 澱粉糊液の老化による影響も検討し た。

\section{2 塗工条件, 測定条件}

調成した塗料を用いてラボにてワイヤーバー塗工を行い, カレンダー処理を行った。得られた塗工紙を恒温恒湿室 $\left(23^{\circ} \mathrm{C}, 50 \%\right)$ で調湿し, 各種測定を行った。表 3 に塗工 条件，表 4, 表 5 に測定条件を示す。

\section{3 澱粉粘度と印刷強度}

澱粉粘度が低いとバインダーとしての強度が低下するた め, 塗工紙の印刷強度が低下する傾向にある。塗料処方(塗 料配合 B)，塗工濃度を全て $63 \%$ にして塗工を行い，澱粉 粘度と強度の関係を確認した。図 4 に示すとおり，同一塗 工条件ならば澱粉粘度が低下すると印刷強度も低下する傾 向がある。但し，HSS コート300 は澱粉粘度が非常に低

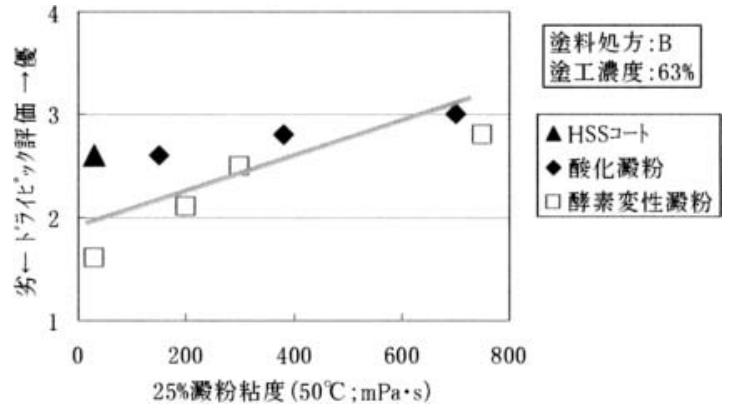

図 4 澱粉粘度と RI 印刷ドライピックの関係

いが印刷強度の低下が小さい。

\section{4 塗工濃度による塗工紙への影響}

塗工濃度を高めると塗工直後の塗工層不動化が早まり, また，バインダーのマイグレーションも抑制できる為，塗 工紙の光沢性や印刷強度が向上すると考えられる。表 6 に 酸化澱粉と HSS コート 300 を用いて塗工濃度を変えた塗 工評価結果を示す。塗工濃度を高くすると透気度は低くな り，光沢度は高くなる傾向がある。また， RI 印刷ドライ ピックは塗工濃度が高くなると向上するが，ウェットピッ クは低下する傾向が見られる。

HSS コート 300 は塗工紙の平滑性，透気性が良く，光 沢度が非常に向上する。また，同一塗工濃度では澱粉粘度 の低いHSS コート 300 は酸化澱粉に比べてドライピック が劣るが，塗工濃度を高めればドライピックが同等になる。 ウェットピックは塗工濃度に関わらず，HSS コート 300 は酸化澱粉よりも HSS コート 300 は塗料粘度が低い為, 塗

表 4 測定条件

\begin{tabular}{l|l}
\hline $\mathrm{B}$ 型粘度 & 東京計器 $\mathrm{B}$ 型粘度計 $(\mathrm{No}$. ローター, $60 \mathrm{rpm})\left[25^{\circ} \mathrm{C} ; \mathrm{mPa} \cdot \mathrm{s}\right]$ \\
\hline ハイシェア粘度 & 熊谷理機 ハーキュレス粘度計 $(\mathrm{F}$ ボブ, $8,800 \mathrm{rpm})\left[25^{\circ} \mathrm{C} ; \mathrm{mPa} \cdot \mathrm{s}\right]$ \\
\hline 保水度 & カルテックサイエンティフィック社 $\mathrm{AA}-\mathrm{GWR}(100 \mathrm{kPa}, 30 \mathrm{sec})\left[25^{\circ} \mathrm{C} ; \mathrm{g} / \mathrm{m}^{2}\right]$ \\
\hline 透気度, 平滑度 & 旭精工 王研式透気度・平滑度計 $[\mathrm{sec}]$ \\
\hline 光沢度 & 村上色彩技術研究所 $\mathrm{GM}-26 \mathrm{D}\left(75^{\circ}\right)[\%]$ \\
\hline
\end{tabular}

表 5 RI 印刷評価

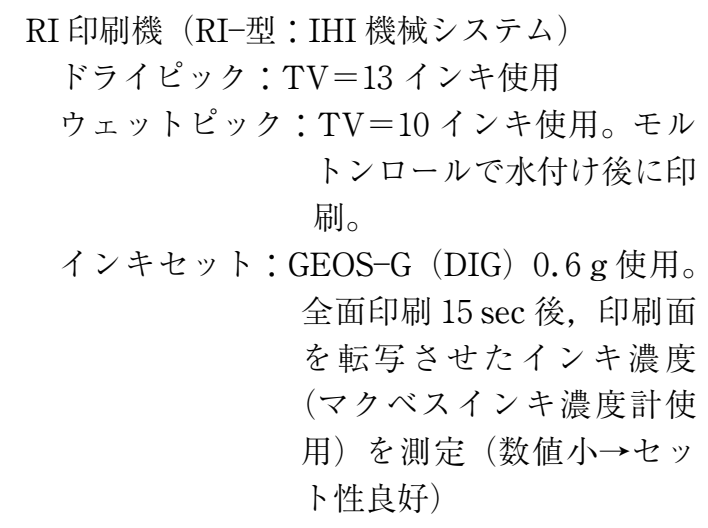

印刷強度評価基準 塗料配合 B の塗工紙を 基準とし，ラテックスの 添加量を変えて強度の目 安とした (目視評価)。
評価点

$5.0 \cdots$ 殆どピッキングが無い

$4.0 \cdots$ 塗料 B（澱粉/ラテックス $=3 / 10.5$ )

$3.0 \cdots$ 塗料 B（澱粉/ラテックス $=3 / 10$ )

$2.4 \cdots$ 塗料 B（澱粉/ラテックス $=3 / 9.5$ )

$1.8 \cdots$ 塗料 B (澱粉/ラテックス $=3 / 9$ )

$1.0 \cdots$ 殆ど全て表面が剥ける 


石田光雄

表 6 塗工濃度による塗工紙の性状変化

\begin{tabular}{|c|c|c|c|c|c|c|c|c|c|c|c|}
\hline \multirow{2}{*}{$\begin{array}{c}\text { サンプル } \\
\text { No. }\end{array}$} & \multirow{2}{*}{$\begin{array}{l}\text { 塗料 } \\
\text { 配合 }\end{array}$} & \multirow{2}{*}{$\begin{array}{l}\text { 塗料 } \\
\text { 濃度 }\end{array}$} & \multirow[t]{2}{*}{ 澱粉 } & \multicolumn{3}{|c|}{ 塗料 } & \multicolumn{3}{|c|}{ 白紙 } & \multirow{2}{*}{$\begin{array}{l}\text { ドライ } \\
\text { ピック }\end{array}$} & \multirow{2}{*}{$\begin{array}{c}\text { ウェット } \\
\text { ピック }\end{array}$} \\
\hline & & & & B-vis & $\mathrm{Hs}^{-}$-vis & 保水度 & 平滑度 & 透気度 & 光沢度 & & \\
\hline 1 & \multirow{4}{*}{ B } & $63 \%$ & HSS コート & 390 & 29.3 & 89 & 2,030 & 1,830 & 66.0 & 2.6 & 3.2 \\
\hline 2 & & $65 \%$ & HSS コート & 550 & 38.0 & 78 & 1,980 & 1,650 & 68.2 & 3.0 & 3.3 \\
\hline 3 & & $63 \%$ & 酸化澱粉 & 850 & 34.2 & 56 & 1,840 & 1,970 & 64.5 & 3.0 & 3.0 \\
\hline 4 & & $65 \%$ & 酸化澱粉 & 1,400 & 40.3 & 50 & 1,790 & 1,700 & 65.6 & 3.1 & 2.8 \\
\hline
\end{tabular}

料濃度を高め易く，塗工紙の品質を向上させることが可能 である。

\section{5 塗工濃度による塗工紙への影響}

塗工濃度を高めると塗工直後の塗工層不動化が早まり, また，バインダーのマイグレーションも抑制できる為，塗 工紙の光沢性や印刷強度が向上すると考えられる。表 6 に 酸化澱粉と HSS コート 300 を用いて塗工濃度を変えた塗 工評価結果を示す。塗工濃度を高くすると透気度は低くな り, 光沢度は高くなる傾向がある。また, RI 印刷ドライ ピックは塗工濃度が高くなると向上するが，ウェットピッ クは低下する傾向が見られる。

HSS コート 300 は塗工紙の平滑性, 透気性が良く, 光 沢度が非常に向上する。また, 同一塗工濃度では潵粉粘度 の低い HSS コート 300 は酸化澱粉に比ベてドライピック が劣るが，塗工濃度を高めればドライピックが同等になる。 ウェットピックは塗工濃度に関わらず，HSS コート 300 は酸化澱粉よりも HSS コート 300 は塗料粘度が低い為, 塗 料濃度を高め易く，塗工紙の品質を向上させることが可能 である。

\section{6 顔料構成による HSS コート 300 の印刷強度に 対する効果}

今回評価した顔料構成はカオリン/炭カルであるが，重 炭に比べてカオリンは多くのバインダー或いは強度の強い バインダーを必要とする事が多い。また，今回使用の軽炭 も同様である。これらは重炭に比べて顔料の表面積が大き く, 分散性が悪い事がバインダーの接着性能を阻害してい ると考える。表 7 に検討した塗料処方, 図 5 にその結果の RI印刷ドライピック評価を示すが，印刷強度が低下し易 い顔料配合の塗工紙の方がHSS コート 300 の強度向上効 果が現れている。HSS コート 300 は粘度が低く, 塗料中 での分散性が良好と考えられる為，カオリンや軽炭の割合 が多いと粘度の高い酸化澱粉に比べて接着性能の効果が現 れ易い。

\section{7 澱粉老化による影響}

塗料用に用いる澱粉は塗料調成を行うまで高濃度, 高温 で保存しなければならない事がある。この様な状態で澱粉 糊液を保存しておくと老化物 (不溶性の結晶化物, 凝集物) が発生し, バインダー機能の低下だけでなく, 塗料凝集物 を発生させ，塗工ムラやストリークの原因にもなる。HSS コート 300 は糊夜の澱粉老化物発生が非常に少ない為, 印 刷強度の低下が小さく, 塗工紙光沢度の低下も小さい（表
表 7 顔料構成違いによる評価の塗料処方

\begin{tabular}{|c|c|c|c|}
\hline $\begin{array}{c}\text { サンプル } \\
\text { No. }\end{array}$ & $\begin{array}{l}\text { 塗料 } \\
\text { 配合 }\end{array}$ & $\begin{array}{l}\text { 塗工 } \\
\text { 濃度 }\end{array}$ & 澱粉種類 \\
\hline 5 & \multirow{2}{*}{ A } & $65 \%$ & HSS コート \\
\hline 6 & & $63 \%$ & 酸化澱粉 \\
\hline 2 & \multirow{2}{*}{ B } & $65 \%$ & HSS コート \\
\hline 3 & & $63 \%$ & 酸化澱粉 \\
\hline 7 & \multirow{2}{*}{$\mathrm{C}$} & $65 \%$ & HSS コート \\
\hline 8 & & $63 \%$ & 酸化澱粉 \\
\hline 9 & \multirow{2}{*}{$\mathrm{D}$} & $65 \%$ & HSS コート \\
\hline 10 & & $63 \%$ & 酸化澱粉 \\
\hline 11 & \multirow{2}{*}{$\mathrm{E}$} & $65 \%$ & HSS コート \\
\hline 12 & & $63 \%$ & 酸化澱粉 \\
\hline 13 & \multirow{2}{*}{$\mathrm{F}$} & $65 \%$ & HSS コート \\
\hline 14 & & $63 \%$ & 酸化澱粉 \\
\hline
\end{tabular}

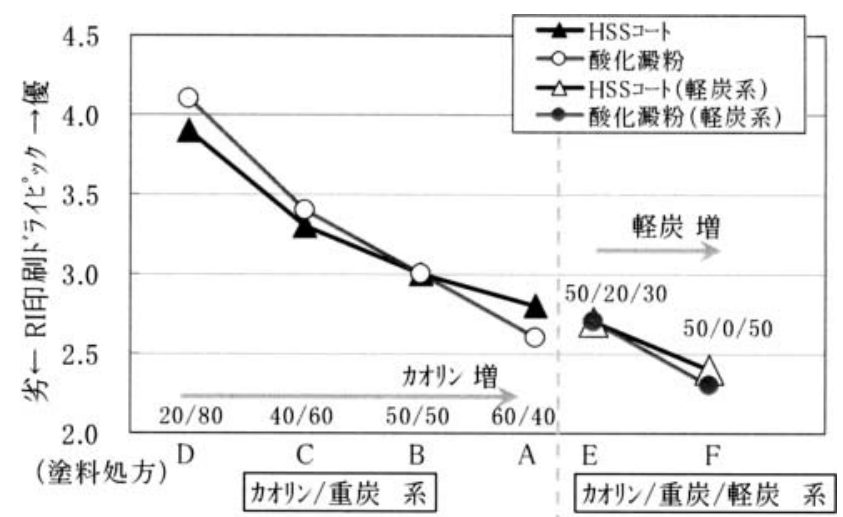

図 5 顔料構成違いによる印刷強度の挙動

8)。

\section{8 塗料調成時に投入する澱粉濃度の影響}

前述の通り HSS コート 300 は非常に低粘度であるにも 関わらず，意外にも高粘度の澱粉に劣らず塗工紙の顔料接 着に効果を与えている。低粘度の為に澱粉と塗料中の成分 の混合が良いと考えられるが，塗料調成時投入の澱粉糊夜 
表 8 澱粉糊液老化による塗工紙の影響

\begin{tabular}{|c|c|c|c|c|c|c|}
\hline $\begin{array}{c}\text { サンプル } \\
\text { No. }\end{array}$ & $\begin{array}{l}\text { 塗料 } \\
\text { 配合 }\end{array}$ & $\begin{array}{l}\text { 塗工 } \\
\text { 濃度 }\end{array}$ & 澱粉種類 & $\begin{array}{c}\text { 光沢度 } \\
(\%)\end{array}$ & $\begin{array}{l}\text { ドライ } \\
\text { ピック }\end{array}$ & $\begin{array}{c}\text { ウェット } \\
\text { ピック }\end{array}$ \\
\hline 15 & \multirow{4}{*}{$\mathrm{B}$} & $65 \%$ & HSS コート 300 (老化処理) * & 67.4 & 2.9 & 3.3 \\
\hline 16 & & $63 \%$ & 酸化澱粉 (老化処理)* & 62.7 & 2.8 & 3.1 \\
\hline 2 & & $65 \%$ & HSS コート 300 & 68.2 & 3.0 & 3.3 \\
\hline 3 & & $63 \%$ & 酸化澱粉 & 64.5 & 3.0 & 3.0 \\
\hline
\end{tabular}

*澱粉糊液老化処理：HSS コートは $35 \%$, 酸化澱粉は $25 \%$ でクッキング後, $80^{\circ} \mathrm{C}, 1$ 時間糊液を保存。この保存糊液（老化処理）を用いて塗料を調整した。

表 9 投入澱粉濃度による評価の塗料処方

\begin{tabular}{|c|c|c|c|c|}
\hline $\begin{array}{c}\text { サンプル } \\
\text { No. }\end{array}$ & $\begin{array}{l}\text { 塗料 } \\
\text { 配合 }\end{array}$ & $\begin{array}{l}\text { 塗工 } \\
\text { 濃度 }\end{array}$ & 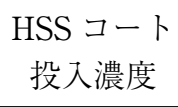 & $\begin{array}{l}\text { 塗料 } \\
\text { 攪汼 }\end{array}$ \\
\hline 17 & \multirow{5}{*}{ B } & \multirow{5}{*}{$65 \%$} & $30 \%$ & 通常 \\
\hline 2 & & & $35 \%$ & 通常 \\
\hline 18 & & & $40 \%$ & 通常 \\
\hline 19 & & & $45 \%$ & 通常 \\
\hline 20 & & & $45 \%$ & 強化 \\
\hline
\end{tabular}

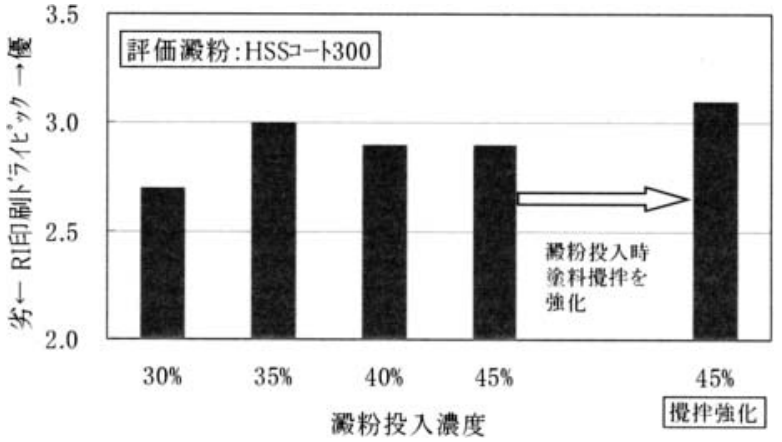

図 6 澱粉投入濃度による塗工紙印刷強度への影響

濃度を変えることで塗工紙の印刷強度に影響がないか検討 した。表 9 に検討した塗料処方と，図 6 にその結果を示す。 塗料に投入する際の澱粉濃度を変えた以外はこれまでどお りの方法で試験を行った。HSS コート 300 は塗料へ投入 する際の澱粉濃度が低いと塗工紙の印刷強度が低下

し，35\%で最も強度を発現し，更に高い濃度では再び強 度が低下する。澱粉の塗料中における分散の問題ならば, 投入する際の澱粉濃度は低い方が良いと考えられるが，強 度発現に濃度がある程度必要である事は, 塗料中で澱粉水

表 10 澱粉部数を増やした処方の評価結果

\begin{tabular}{|c|c|c|c|c|c|}
\hline \multicolumn{2}{|c|}{ サンプル No. } & 21 & 22 & 2 & 3 \\
\hline \multicolumn{2}{|l|}{ 塗料配合 } & \multicolumn{2}{|c|}{ G（澱粉/ラテックス＝4.5/9） } & \multicolumn{2}{|c|}{$\mathrm{B} （$ 澱粉/ラテックス $=3 / 10 ）$} \\
\hline \multicolumn{2}{|l|}{ 塗工濃度 } & $65 \%$ & $63 \%$ & $65 \%$ & $63 \%$ \\
\hline \multicolumn{2}{|l|}{ 澱粉種類 } & HSS コート & 酸化澱粉 & HSS コート & 酸化澱粉 \\
\hline \multirow[t]{3}{*}{ 塗料 } & $\mathrm{B}$-vis & 720 & 1,680 & 550 & 850 \\
\hline & Hs-vis & 40.0 & 41.0 & 38.0 & 34.2 \\
\hline & 保水度 & 66 & 40 & 78 & 56 \\
\hline \multirow[t]{3}{*}{ 白紙 } & 平滑度 & 1,920 & 1,700 & 1,980 & 1,840 \\
\hline & 透気度 & 1,680 & 2,000 & 1,650 & 1,970 \\
\hline & 光沢度 & 66.4 & 61.6 & 68.2 & 64.5 \\
\hline \multirow[t]{3}{*}{ RI 印刷 } & トライピック & 3.1 & 3.3 & 3.0 & 3.0 \\
\hline & ウェットピック & 2.8 & 2.7 & 3.3 & 3.0 \\
\hline & インキセット* & 0.51 & 0.56 & 0.47 & 0.50 \\
\hline
\end{tabular}

*インキセット：数值小 $\rightarrow$ 良好 
和体（糊液）がある程度の密度と大きさを持った形態で存 在する必要があると推測する。また， $45 \%$ の高濃度糊液 を投入した際，塗料調成時の攪拌を強化すると塗工紙の強 度が向上することから, 投入時の澱粉濃度がある程度以上 高いと塗工紙の強度が低下するのは, 澱粉粘度が非常に大 きくなり分散が悪くなる為と考えられる。

\section{9 澱粉部数を増やした検討}

澱粉はラテックスに比べて顔料の接着性に劣るが, 添加 部数を増やす事で強度維持が可能である。しかし, バイン ダーの総部数が増えると, 塗料物性や叙工紙の品質に大き く影響を与える場合がある。特に澱粉は塗工紙の光沢性, 平滑性, 透気性, インキセット性を低下させる要因である 事が多い。HSS コート300は前述の検討から, 通常の澱 粉に比べてこれら負の要因が小さい為, 塗料への澱粉増添 の可能性がある。ラテックスを 1 部減添し，代わりに澱粉 を 1.5 部増添した処方で作成した塗工紙を評価した。表 10 に結果を示す。

澱粉を増添したサンプル（No.21，No.22）は塗料の粘 度が上昇したが, 酸化澱粉は特に粘度の上昇が大きくなっ た。塗工紙の白紙品質においては, HSS コート 300 は光 沢度, 平滑度の低下が小さく, 酸化澱粉は大きくなった。 また，RI印刷においては，ラテックスを減添し澱粉を増 添する事でドライピックは維持できたが，澱粉が多く含ま れる為に水の吸収が良くなりウェットピックがやや劣る結 果となった。インキセットも悪くなる傾向であった。しか し, HSS コート 300 の澱粉増添サンプルは, 基準となる
酸化澱粉サンプル（No.3）と比べると，白紙品質，印刷 適性は特に大きく劣る事もなく, 澱粉増添による塗工紙品 質への影響は酸化澱粉に比べて小さいと考えられる。

\section{4. まと め}

HSS コート 300 は非常に粘度の低い澱粉である為, 高 濃度のクッキングが可能であり, 塗料の高濃度化が行い易 い。また, 澱粉の老化性が非常に小さく, 糊液流動性, 粘 度安定性, 保存安定性に優れる為, 高温, 高濃度で港粉糊 液を取り扱う塗料調成においては作業性が良くなる。

澱粉は塗工紙への光沢性, 平滑性, 透気性, 印刷適性に 大きな影響を与えるが, HSS コート 300 はこれら品質に 与える負の影響が小さく, 澱粉の増添も可能である。これ まで非常に粘度の低い澱粉は塗料用バインダーとして利用 されていなかったが，その一番の理由は低粘度故の接着力 の低下であった。しかし, 非常に粘度の低い HSS コート 300 は塗料を高濃度化することにより塗料中の顔料接着を 効果的に行い，塗工紙の強度を維持する事が可能である。 特にバインダーを多く必要とする顔料に対して, 塗料中の 分散性が良いHSS コート 300 は顔料接着の効果を発揮す る。

これまでにない超低粘度澱粉 HSS コート 300 は塗料用 澱粉として様々な可能性を秘めていると考える。新たな塗 料処方を生み出し，塗工紙の製造に貢献できるよう，更な る検討を続ける。 